\title{
Emergent Rainy Winter Warm Spells May Promote Boreal Predator Expansion into the Arctic
}

\author{
Aleksandr A. Sokolov, ${ }^{1,2,3}$ Natalya A. Sokolova, ${ }^{1,2}$ Rolf A. Ims, ${ }^{4}$ Ludovic Brucker ${ }^{5,6}$ and Dorothee Ehrich ${ }^{3,4}$
}

(Received 28 May 2015; accepted in revised form 9 November 2015)

\begin{abstract}
Climate change has been characterized as the most serious threat to Arctic biodiversity. In addition to gradual changes such as climate warming, extreme weather events, such as melting temperatures in winter and rain on snow, can have profound consequences for ecosystems. Rain-on-snow events lead to the formation of ice layers in the snow pack, which can restrict access to forage plants and cause crashes of herbivore populations. These direct impacts can have cascading effects on other ecosystem components, often mediated by trophic interactions. Here we document how heavy rain in early winter, leading to the formation of a thick layer of ice, was associated with dramatic mortality of domestic reindeer on Yamal Peninsula, Russia. In the subsequent summer, breeding of two boreal generalist predators, red fox and Hooded Crow, was recorded for the first time in a monitoring area in the Low Arctic tundra of this region. We suggest that the resource pulse created by the abnormally high reindeer mortality and abundance of carrion may have facilitated these breeding events north of the known breeding range of the two species. Our observations provide an example of how specific emergent weather events may indirectly pave the way for more abrupt, although possibly temporary, species range changes.
\end{abstract}

Key words: Arctic fox (Vulpes lagopus); red fox (Vulpes vulpes), Hooded Crow (Corvus cornix); domestic reindeer; ground icing; rain on snow; food web; range expansion

RÉSUMÉ. Le changement climatique a été caractérisé comme la plus grande menace à la biodiversité de l'Arctique. En plus des changements graduels comme le réchauffement climatique, les phénomènes météorologiques extrêmes comme les températures positives en hiver et la pluie tombant sur la neige peuvent avoir de profondes conséquences sur les écosystèmes. La pluie tombant sur la neige mène à la formation de couches de glace dans le manteau neigeux, ce qui peut avoir pour effet de restreindre l'accès aux plantes fourragères et d'entraîner l'effondrement des populations herbivores. Ces impacts directs peuvent avoir des effets en cascade sur d'autres composantes des écosystèmes, et cette propagation passe souvent par des interactions trophiques. Dans cette communication, nous décrivons comment une pluie abondante en début d'hiver, menant à la formation d'une couche de glace épaisse, a été accompagnée par une mortalité dramatique des rennes domestiques dans la péninsule de Yamal, en Russie. L'été suivant, la reproduction de deux prédateurs boréaux généralistes, soit celui du renard roux et celui de la corneille mantelée, a été enregistrée pour la première fois dans une aire d'étude de la toundra du Bas-Arctique de cette région. Nous suggérons que l'abondance de ressources créée par le taux de mortalité anormalement élevé de rennes et l'abondance de charognes aurait pu susciter ces épisodes de reproduction au nord de l'aire de répartition connue des deux espèces. Nos observations fournissent un exemple selon lequel des phénomènes météorologiques émergents particuliers peuvent, indirectement, ouvrir la voie à des changements plus abrupts en matière d'aire de répartition des espèces, bien que ces changements puissent être temporaires.

Mots clés : renard arctique (Vulpes lagopus); renard roux (Vulpes vulpes), corneille mantelée (Corvus cornix); renne domestique; englacement du sol; pluie tombant sur la neige; réseau alimentaire; agrandissement de l'aire de répartition

Traduit pour la revue Arctic par Nicole Giguère.

РЕЗЮМЕ. В настоящее время, изменения климата представляются наиболее серьезной угрозой для биоразнообразия Арктики. В дополнение к постепенным изменениям, таким как потепление климата, экстремальные погодные явления (зимние потепления до температуры таяния или жидкие осадки на снежный покров) могут иметь серьезные последствия для экосистем. Погодный феномен «дождь-на-снег» приводит к формированию слоев льда в снежном покрове, что может ограничивать доступ к кормовым растениям, и явиться причиной падения популяций

\footnotetext{
${ }^{1}$ Arctic Research Station of Institute of Plant and Animal Ecology, Ural Branch, Russian Academy of Sciences, Labytnangi, Russia

${ }^{2}$ Science Center for Arctic Studies, State Organization of Yamal-Nenets Autonomous District, Salekhard, Russia

${ }^{3}$ Corresponding authors: sokhol@yandex.ru and dorothee.ehrich@uit.no

${ }^{4}$ University of Tromsø - The Arctic University of Norway, Department of Arctic and Marine Biology, Tromsø, Norway

${ }^{5}$ NASA Goddard Space Flight Center, Cryospheric Sciences Laboratory, Code 615, Greenbelt, Maryland 20771, USA

${ }^{6}$ Universities Space Research Association, GESTAR, Columbia, Maryland 21046, USA

(C) The Arctic Institute of North America
} 


\begin{abstract}
травоядных. Подобные прямые воздействия могут привести к каскадным эффектам на другие компоненты экосистем, часто через трофические взаимодействия. В настоящем сообщении мы документируем, как сильные дожди в начале зимы привели к формированию толстого слоя льда, что, по всей видимости, явилось причиной катастрофической смертности домашних северных оленей на полуострове Ямал в России. В следующее лето на мониторинговой площадке в кустарниковой тундре Ямала впервые было зарегистрировано размножение двух хищников-генералистов из бореальной зоны - обыкновенной лисы и серой вороны. Мы предполагаем, что ресурсный импульс, обеспеченный аномально высокой смертностью оленей и, как следствие, обилием падали, мог способствовать появлению случаев размножения этих двух видов к северу от известной границы их распространения. Наши наблюдения являются примером того, как возникающие экстремальные погодные явления могут опосредованно проложить путь к более резким, хотя вероятно и временным, изменениям ареала видов.
\end{abstract}

Ключевые слова: песец (Vulpes lagopus); лиса (Vulpes vulpes), серая ворона (Corvus cornix); домашний северный олень; ледяная корка; дождь-на-снег; трофическая сеть; увеличение ареала

\section{INTRODUCTION}

Climate change is more rapid in the Arctic than in other areas of the world and has been characterized as the most serious threat to Arctic biodiversity (Meltofte et al., 2013). Many of the documented trends of change in terrestrial ecosystems, such as northwards range shifts of boreal species, increase in the growth of shrubs or changes in carbon budget are responses to gradual changes in climate, such as rising temperature or earlier snowmelt (Ims et al., 2013a). In addition to such trend effects, extreme weather events, which are predicted to increase in frequency and magnitude, can have profound consequences for ecosystems (Jentsch et al., 2007; Bokhorst et al., 2008; Hansen et al., 2014). Such events can accelerate shifts in species composition and distribution (Wernberg et al., 2013) and induce transitions between ecosystem states that are not always easily reversible (Mueller et al., 2005; Jentsch et al., 2007). In addition to direct impacts on climate-sensitive species or processes, both trend effects and consequences of extreme weather events can have cascading effects on other ecosystem components, effects that are often mediated by trophic interactions (Post et al., 2009; Ims et al., 2013a).

A consequence of a warmer and wetter climate is an increase in the frequency of periods of melting temperatures during winter and of rain-on-snow events in some regions of the Arctic (AMAP, 2011). These events can have catastrophic consequences for plant and animal populations. Refreezing after rain or melting periods in winter leads to the formation of ice layers in the snow pack or on the ground surface. This ice prevents herbivores from accessing their food, which can cause heavy mortality in populations of large herbivores such as reindeer (Rangifer tarandus; Aanes et al., 2000; Miller and Gunn, 2003), and may become a major problem for reindeer husbandry (Moen, 2008). Rain-on-snow events have been rare in most of the Arctic (Rennert et al., 2009). In the oceanic climate of High Arctic Svalbard, however, winter rain has been a normal (but stochastic) feature of the weather pattern for decades, although recent events appear to have become more important than before (Hansen et al., 2014). These events in Svalbard cause synchronized crash-recovery dynamics within the entire winter-resident vertebrate community
(Hansen et al., 2013). Weather-induced winter mortality of reindeer and other herbivores appears to be the key ingredient of these dynamics.

Ungulate carcasses can be a valuable food resource for carnivores in northern winters (Wilmers et al., 2003). Studies of Arctic foxes (Vulpes lagopus) in Svalbard have shown that more foxes were breeding in inland dens after winters with high reindeer mortality and thus good access to food from carcasses (Fuglei et al., 2003; Eide et al., 2012). In Subarctic and Low Arctic Norway, higher densities of resident semi-domestic reindeer provide more potential carrion in winter, leading to a strong increase in the presence of all carnivore species, but particularly of typical boreal forest mesopredators such as red foxes (Vulpes vulpes), Hooded Crow (Corvus cornix), or eagles (Aquila chrysaetos and Haliaetus albicilla; Henden et al., 2014). In the same region, diet analyses revealed that reindeer carrion was a key resource for red foxes during winters with low lemming (Lemmus lemmus) abundance in the tundra (Killengreen et al., 2011).

The expansion of widespread generalist predators into the Arctic tundra is one of the ongoing trends in changes affecting terrestrial Arctic ecosystems (Ims et al., 2013a). Subarctic generalists such as red fox or Hooded Crow can have a negative impact on native Arctic species. For example, interspecific competition with the larger red fox is one of the major causes for the decline of the endangered Arctic fox in northern Fennoscandia (Tannerfeldt et al., 2002; Angerbjörn et al., 2013). Moreover, red foxes and corvids are important nest predators (Ims et al., 2013b) and have been hypothesized to contribute to the decline of Willow Ptarmigan (Lagopus lagopus; Henden et al., 2011; Ehrich et al., 2012) and Lesser White-fronted Geese (Anser erythropus; Norwegian Directorate for Nature Management, 2011) in the same region.

Henden et al. (2014) suggest that increased access to reindeer carrion in late winter may allow forest-dwelling mammalian mesopredators and corvids to establish and breed in tundra. Anthropogenic subsidies from deliberate feeding or waste are known to enhance breeding both in red foxes (Angerbjorn et al., 1995; Stickney et al., 2014) and in ravens (Corvus corax) (Newton et al., 1982). However, we are not aware of studies that have directly linked the establishment 
of boreal predators in Low Arctic tundra to specific weather events. Here we document how a pulse of resources caused by exceptional mortality of domestic reindeer after a rainon-snow event was followed by the first records of breeding by boreal generalist predators in Low Arctic Yamal, Russia. Our observations contribute to the growing understanding of how important emergent extreme weather events are in driving ecosystem change and highlight the role of subsidies in modifying the composition of the tundra predator guild.

\section{MATERIAL AND METHODS}

\section{Study Area}

The study was carried out at the Erkuta Tundra Monitoring Site in the southern part of Yamal Peninsula, Russia $\left(68.2^{\circ} \mathrm{N}, 69.2^{\circ} \mathrm{E}\right.$; Fig. 1). This Low Arctic area (bioclimatic zone E; Walker et al., 2005) is characterized by a gently rolling tundra landscape with low hills (ca. $30 \mathrm{~m}$ high), including some steep slopes and sandy cliffs along riverbanks and lakes (Sokolov et al., 2012). Mean temperature in the area is $-24.1^{\circ} \mathrm{C}$ in January and $11.4^{\circ} \mathrm{C}$ in July, and mean annual precipitation is about $335 \mathrm{~mm}$ (averages for the period 1950-2000; downloaded from www. worldclim.org). A stable snow cover is usually established in October and lasts until early June. Rain-on-snow events are typically rare in the western Siberian Arctic (Groisman et al., 2003; AMAP, 2011). For southern Yamal, the study by Groisman et al. (2003) reports an average frequency of 0 such events per winter in the period 1950-2000 (Noviy Port weather station). The vegetation has been classified mostly as low shrub tundra, with erect dwarf shrub tundra in drier places (Walker et al., 2005; Magomedova et al., 2006). The area is situated ca. $150 \mathrm{~km}$ north of the southern border of the tundra area as defined by the circum-Arctic vegetation map (Fig. 1; Walker et al., 2005). Forest also extends northwards into the tundra area along the valley of a larger river (Shuch'ya), and the northernmost forest patches are found ca. $110 \mathrm{~km}$ south of our study area. Numerous water bodies create extensive wetlands, and dense thickets of willows and in some places alders occur along rivers and lakes.

The small rodent community is dominated by two species of Microtus voles (M. middendorffi and M. gregalis) and has during the last decade exhibited multi-annual fluctuations of rather low amplitude (Sokolova et al., 2014). Forty-one species of birds, including numerous waterfowl, passerines and waders, are breeding in the area (Sokolov et al., 2012). The medium-sized herbivores, Willow Ptarmigan and mountain hare (Lepus timidus), are relatively abundant (Ehrich et al., 2012). The Yamal Peninsula is a traditional Nenets reindeer-herding region. Reindeer numbers have increased over the last decades (Klokov, 2012) to more than 300000 on the peninsula at present. Our study area is used by reindeer herds in all seasons. Some of these herds migrate over long distances, and others are more local.
The most common mammalian predator is the Arctic fox, but least weasel (Mustela nivalis), stoat (M. erminea), wolverine (Gulo gulo), and wolf (Canis lupus) are also present. Red foxes are rare, but they are sometimes observed in winter and have been shot (three times to our knowledge) by Nenets people living in the study area in the years 2007-13. Since 2008, single red foxes have been registered in some years on automatic cameras with baits in late winter (A.A. Sokolov, unpubl. data). In summer, only a few observations of red foxes have been recorded, although the species is unusual for the area and thus conspicuous, which implies that observations would certainly have been written down. A red fox pup was observed in 1989 on the banks of the Erkuta River (V.G. Shtro, pers. comm. 2015). Annual monitoring of small rodents and birds was initiated in the area in 1998. Since then red foxes have been observed in only two summers. Two individuals were recorded in 2007. One of them intruded on an Arctic fox den, leading to the abandonment of the den by the Arctic fox family (Rodnikova et al., 2011). In 2013 a single individual was observed close to a den at the periphery of the study area. Red foxes are regularly breeding in the forested Shuch'ya valley (S.A. Mechnikova, pers. comm. 2015), ca. $110 \mathrm{~km}$ south of our study area.

The most common birds of prey in the area are Roughlegged Buzzards (Buteo lagopus), Peregrine Falcons (Falco peregrinus), and Long-tailed and Arctic Skuas (Stercorarius longicaudus and $S$. parasiticus). Ravens have been breeding in the study area since 2009. They were able to establish themselves after the construction of a railroad bridge across the Erkuta River in 2008. Hooded Crows have been recorded in late spring or summer, but no signs of reproduction have been observed. Breeding of Hooded Crows north of forested areas on Yamal has previously been observed only around settlements (Golovatin and Sokolov, 2009).

\section{Data Collection}

The extreme weather event with heavy rain in November 2013 was documented by direct observations, the recollections of local people, and data from weather stations. In addition, we used information from satellite microwave sensors to determine the extent of the area affected. Passive (radiometer) or active (scatterometer) satellite microwave sensors allow the identification of regions that experienced icing conditions resulting from rain-on-snow events or melt-and-refreeze cycles (e.g., Grenfell and Putkonen, 2008; Bartsch et al., 2010). The algorithm used here is based on satellite observations from the Advanced Microwave Scanning Radiometer 2 (AMSR2) obtained at frequencies of 18.7, 36.5, and $89 \mathrm{GHz}$ (L. Brucker, A. Ivanoff, and N. Maynard, unpubl. data). The algorithm includes a combination of temporal and spectral detection of rain-onsnow events. AMSR2 satellite observations were obtained from the JAXA GCOM-W1 Data Providing Service (https://gcom-w1.jaxa.jp/). The remote sensing data were validated with data from 10 official weather stations 


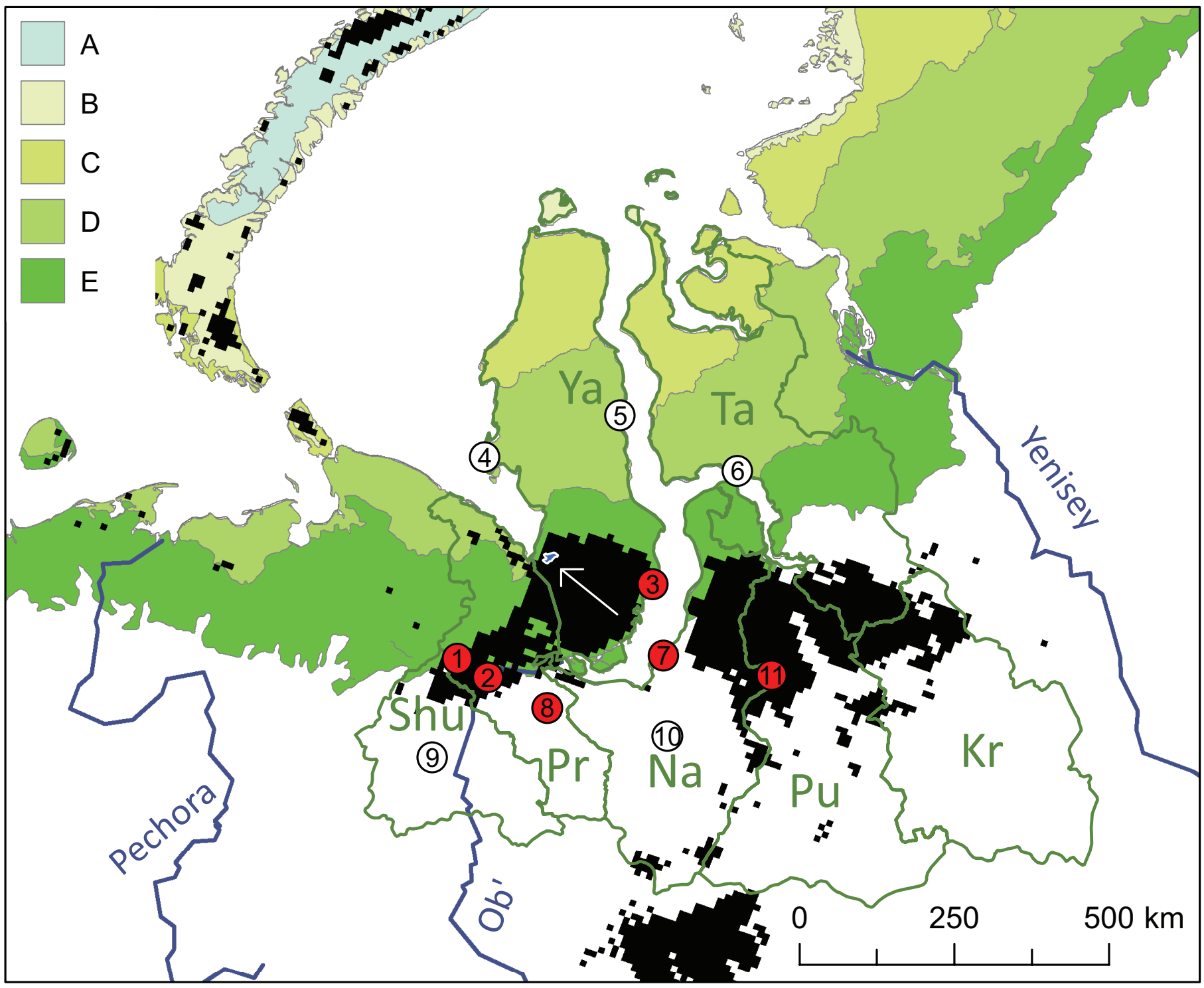

FIG. 1. Map of the Yamalo-Nenetskiy Autonomous District in Northwest Siberia (Russia) with Yamal Peninsula in the center. The five bioclimatic subzones of the Arctic (A-E; Walker et al., 2005) are shown in various shades of green. The seven districts (Ya - Yamalskiy, Ta - Tazovskiy, Shu - Shuryshkarskiy, $\mathrm{Pr}$ - Priuralskiy, $\mathrm{Na}$ - Nadymskiy, Pu - Purovskiy and $\mathrm{Kr}$ - Krasnoselkupskiy) are outlined in green. The blue spot in southern Yamalskiy District represents the study area. Black shading shows areas where surface freezing after the rain-on-snow event was inferred from satellite microwave sensor data. Numbered circles represent weather stations (1 - Polar Ural, 2 - Salekhard, 3 - Noviy Port, 4 - Maresale, 5 - Seyakha, 6 - Antipayuta, 7 - Nyda, 8 - Yangi Yugan, 9 - Muzhi, 10 - Nadym, 11 - Noviy Urengoy). Red circles indicate stations that registered rain on 8-9 November 2013, and white circles show stations that did not record rain.

(obtained from www.rp5.ru) and one additional station in the Polar Urals (V. Ivanov and V. Mazepa, pers. comm. 2015).

Estimates of the number of dead reindeer were obtained from official sources (Government of Yamalo-Nenetskiy Autonomous District) and supplemented by qualitative information from local residents.

Since 1998, the abundance of small rodents and their main predators has been monitored in the study area, though with varying intensity. Birds of prey have been studied since 1999 (Sokolov, 2003) and the whole bird community was surveyed in detail in the period 2002-09 (Sokolov et al., 2012). Systematic Arctic fox den surveys have been carried out each summer since 2007. This survey began with a core area of ca $130 \mathrm{~km}^{2}$ that comprised most breeding dens known at that time (Rodnikova et al., 2011). In subsequent years, the study area was progressively enlarged, and new dens were described. In 2014, the area covered $230 \mathrm{~km}^{2}$ and comprised 21 dens in which breeding had occurred at least once since 2007, as well as 22 other dens with four entrances or more (Fig. 2). All known dens were checked annually for signs of fox activity and breeding. Since 2009, active dens have been monitored with automatic cameras to determine the number of pups. 


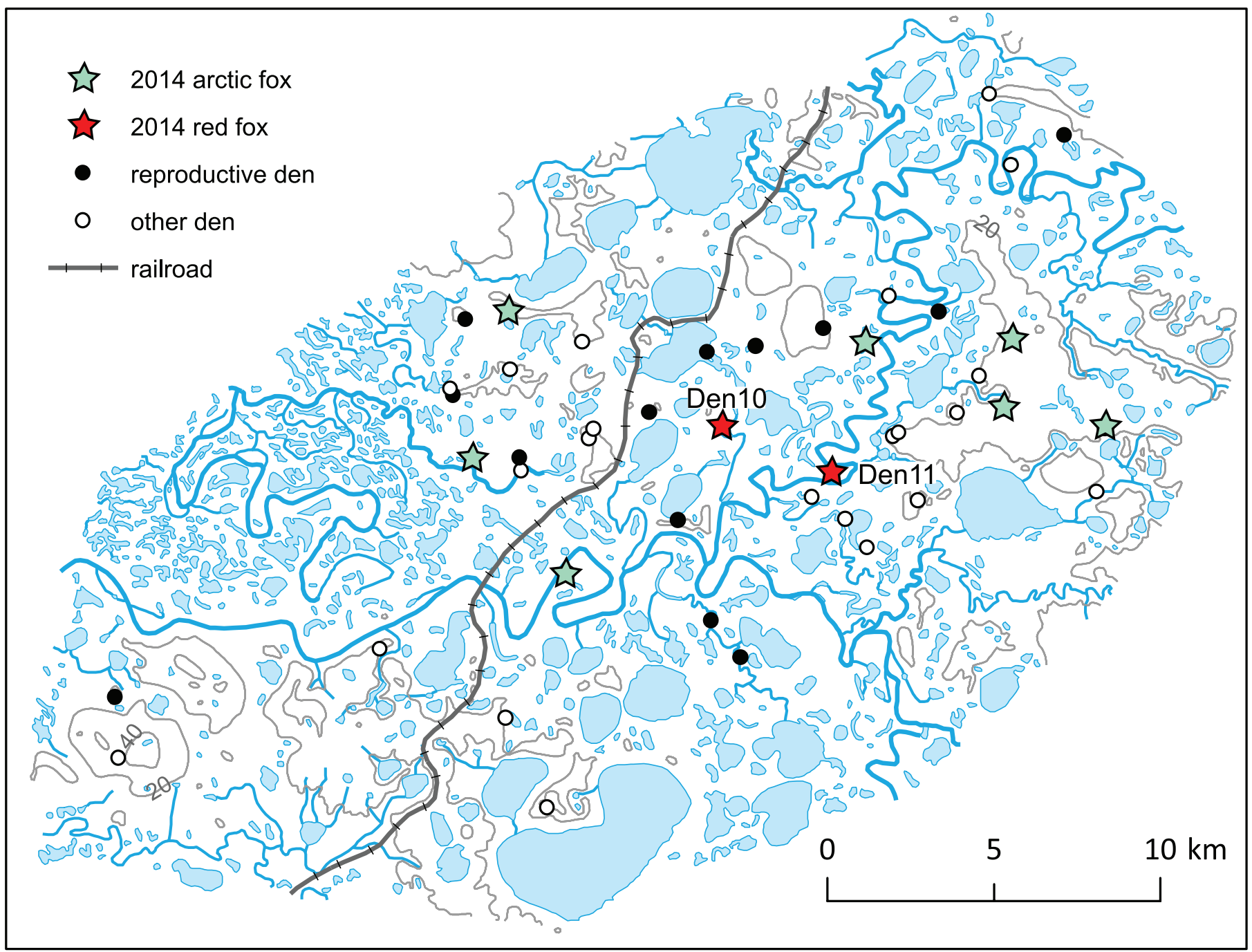

FIG. 2. Map of the study area at Erkuta in southern Yamal. Red stars show the two dens occupied by red foxes in 2014, and pale blue stars show active Arctic fox dens in 2014. Filled black circles represent Arctic fox dens where breeding has been observed since 2007, and open circles show dens where no breeding was observed. The Gazprom railroad Obskaya-Bovanenkovo crosses the area.

\section{RESULTS}

\section{Icing Event}

According to resident Nenets people, a rather deep snow cover was established in the study area on 23 September 2013 - about three weeks earlier than usual — during a three-day snowstorm. On 8 and 9 November, heavy rain fell on the snow-covered ground and led to the formation of a solid ice layer over large parts of the tundra. Positive temperatures and rain were registered at Noviy Port weather station, which is the closest weather station to our study area (Fig. 3). From the satellite data, ground icing due to the rain-on-snow event was inferred for a large area that encompassed our study area and covered the whole southern part of Yamal Peninsula, as well as parts of the Nadymskiy, Purovskiy, and Tazovskiy districts farther east (Fig. 1). The spatial extent of the rain-on-snow event was confirmed by available data from weather stations. Rain was recorded in the area that experienced icing, but not in northern Yamal or in areas farther south (Fig. 1). After that first event, more rain fell in December, forming a solid ice layer at the bottom of the snow pack. This event was registered as sleet in Noviy Port (Fig. 3). This weather station is situated $165 \mathrm{~km}$ east of the study area on the eastern coast of Yamal, so it is likely to experience slightly different weather. The ice layer did not melt until spring, blocking access to the field-layer vegetation for several months. The thickness of the ice layer was not measured.

\section{Reindeer Mortality}

We visited the study area several times between January and April 2014, and every time, herders told us that many of their reindeer had died and that the situation was very difficult. According to official data, 40000 reindeer died in Yamalskiy district (in which our study area is situated) and 15500 in the adjacent Priuralskiy district. No statistics were available about reindeer mortality in winters without icing. Herders estimated, however, that in winter 2013-14 


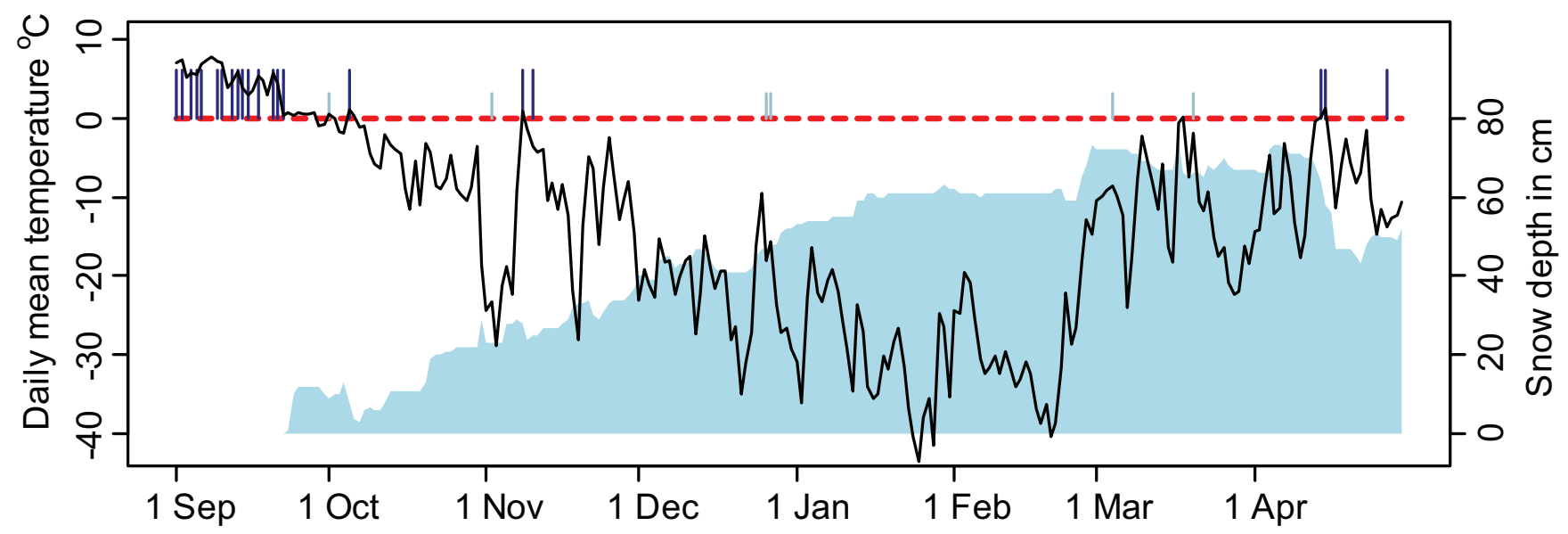

FIG. 3. Weather recorded at Noviy Port weather station in winter 2013-14. The black line traces mean daily temperature, whereas the red dotted line indicates $0^{\circ} \mathrm{C}$. The vertical blue bars indicate days when precipitation was recorded (higher dark blue bars for rain, and lower light blue bars for sleet). Light blue shading indicates snow; however, since snow depth was not recorded in Noviy Port, it shows depth registered at the Salekhard weather station (situated farther south in the region; see Fig. 1).

reindeer mortality was about 10 times higher than usual. When working in the study area in summer, we found numerous reindeer carcasses.

\section{Generalist Predator Reproduction}

During the period 2007 to 2013 , we found on average 4.4 dens (range: $0-8$ ) with reproducing Arctic foxes in the study area, which corresponds to $2.6 \pm 1.9$ dens per $100 \mathrm{~km}^{2}$. No reproduction by red foxes was observed, but a single red fox was observed on a den in 2007 (Rodnikova et al., 2011). In 2014, we registered seven dens occupied by Arctic fox families and discovered two dens with red fox pups. The dens where red fox were breeding were situated in the core of the study area (Fig. 2). On 18 June 2014, four pups were observed playing on den 10 , a rather old den situated close to a lake, where Arctic foxes had not reproduced since 1999. An adult with unusual black and yellowish coat color approached, barked, and ran away. Later in the day, we went back to the den to inspect it and set up an automatic camera. The den showed clear signs of activity: a lot of feces, trampled vegetation, and remains of feathers and fish. The pictures from the automatic camera revealed six red fox pups, two dark morphs and four typical red morphs. No adult was recorded, and the last picture of a pup was taken on 19 June at 23:55. After that, no fox activity was recorded on the den, indicating that the pups were moved.

The other red fox breeding was recorded on 21 June in den 11, situated on a small peninsula created by a sharp turn of the river (Fig. 2), a den where Arctic foxes had been breeding in 2007 . We noticed activity when observing the den from the river, at a distance of $300 \mathrm{~m}$. We saw three red fox pups, clearly identified by their body shape, relatively big ears, and red fur. Later in the day we returned to the den to inspect it and set up an automatic camera. On that visit, we saw six pups playing on the den. The pictures from the automatic camera confirmed the number of pups. Unlike the foxes in den 10, those on this den did not move after the disturbance, and the last picture of a pup was taken on 3 July.

The first nest of a Hooded Crow ever recorded in the study site was found on 24 June. The nest was built about $2 \mathrm{~m}$ above ground on a willow shrub ca $4 \mathrm{~m}$ high. There were three chicks in the nest, and two adults were alarm calling.

On 3 August, we observed a dark red fox pup on the bank of the Erkuta River, which suggested that at least some of the dark pups from den 10 had survived. In winter 2014-15, the local Nenets people shot five red foxes in the study area, compared to only three in total in the period $2008-14$.

\section{DISCUSSION}

Our observations from southern Yamal in 2013-14 suggest that an extreme climatic event, in this case strong rain falling on snow and frozen ground in November, likely induced abnormally high reindeer mortality and thus a large pulse of resources for scavenging carnivores. We suggest that this reindeer die-off was the proximate factor that facilitated the first recorded breeding of two boreal generalist predators/scavengers in the Low Arctic tundra of the Yamal Peninsula and mediated the indirect effect of an extreme weather event (i.e., melting temperatures and rain in winter) on predators by increasing a food resource (i.e., reindeer carrion). Reindeer mortality during winter and the availability of reindeer carrion has indeed been shown to be related to Arctic fox den occupancy on Svalbard (Fuglei et al., 2003; Eide et al., 2012). Eide et al. (2012) suggest also that litter size in Arctic foxes is determined by resource abundance in winter. For red foxes, supplementary feeding at dens in northern Finland during late winter and spring enhanced breeding (Kaikusalo and Angerbjörn, 1995). In northern Norway, both the proportion of pregnant vixens and the proportion of juveniles in the population were 
correlated with resource availability during winter (Killengreen et al., 2013). Red foxes are mobile opportunistic feeders that roam into tundra areas. We suggest that because they encountered abundant resources-many carcasses were rather intact in spring, and reindeer of the weakened herds died also in spring and summer - they may have settled down to breed. The same may have been the case for Hooded Crows, which previously had been observed in our study area only as single birds, but bred in 2014 given the unusually good resource basis. This species is also known to be an opportunistic feeder and takes advantage of carcasses (Killengreen et al., 2012).

The suggested causal relationships linking the icing event, reindeer mortality, access to carrion, and presence of generalist predators in a new area are further supported by studies from southern Yamal in 2006-07. Indeed in that winter unusual successive icing events occurred on southern Yamal starting in November (Forbes et al., 2009; Bartsch et al., 2010). As in 2013-14, the ice blocked the access to pastures for domestic reindeer and resulted in important losses of animals (Forbes et al., 2009). In summer 2007, two red foxes were recorded in our study area, one of which intruded on an Arctic fox den leading to abandonment of the den (Rodnikova et al., 2011). Moreover, the highest breeding activity of Arctic foxes was recorded in the study area in that year ( 8 out of 12 known breeding dens were active, resulting in six Arctic fox pairs per $100 \mathrm{~km}^{2}$ ). Although red fox breeding was not documented in 2007, it may have occurred outside of the surveyed area.

The importance of additional resources or subsidies for the expansion and establishment of red foxes in tundra areas has long been recognized. Hersteinsson and Macdonald (1992) suggested that red foxes could benefit from an increase in primary and secondary productivity induced by climate warming. Some support for this hypothesis has been obtained in northeastern Norway, where red foxes seem to have replaced Arctic foxes in the most productive denning habitat (Killengreen et al., 2007). In other areas of the Arctic, however, red and Arctic fox populations have been stable over several decades despite pronounced climate warming (Gallant et al., 2012), which indicates that increased primary production did not necessarily favor red foxes. Other evidence suggests that resource subsidies in winter, which are often provided by human activity, have played a decisive role for the growth of red fox populations in tundra areas in northern Fennoscandia (Kaikusalo and Angerbjörn, 1995; Killengreen et al., 2011) and Alaska (Savory et al., 2014; Stickney et al., 2014). Although little is known about the expansion of corvids into the Arctic, anthropogenic resources appear to be important as well (Restani et al., 2001). Thus our observations are in agreement with the general pattern of subsidies favoring generalists. However, whereas the studies mentioned above address gradual changes in resource levels, we documented the way in which a weather-induced pulse of resources allowed at least a temporary range expansion of boreal/subarctic predators.
At present, extreme weather events in the Arctic occur in addition to ongoing trends of change such as climate warming and changes in land use. In southern Yamal, the abundance of semi-domestic reindeer has indeed increased considerably over the last decades (Klokov, 2012). Together with the rapid development of extractive industries in the region, the high numbers of animals may make the herds particularly vulnerable (Forbes et al., 2009; Golovatin et al., 2012). As rain-on-snow events are predicted to increase in frequency in the Arctic with ongoing climate change (Rennert et al., 2009), reindeer herders will have to adapt to a more frequent risk of winter icing, and future management options may be determinant for the expansion of boreal generalist predators. A combination of trend effects with stepwise changes due to specific events and modulated by management decisions is likely to be typical for global change-induced ecosystem changes (Jentsch et al., 2007).

Only future observations will show whether, after this first breeding record, red foxes and Hooded Crows will manage to establish in Erkuta, leading to a permanent range expansion, or whether they will not be able to breed there after winters with low reindeer mortality. The future availability of reindeer carrion will depend on the frequency of winter icing and on herd management with respect to icing risk. The abundance of alternative prey, such as hare or waterfowl, may also play a role, but it is difficult to make any predictions about their future population changes. A possible lasting change in the composition of the predator guild with more boreal generalists is likely to have a detrimental impact on many typical Arctic species, in particular ground-nesting birds, such as ptarmigan or waders, and Arctic foxes (McKinnon et al., 2010; Angerbjörn et al., 2013; Ims et al., 2013b).

\section{ACKNOWLEDGEMENTS}

We thank the Laptander family for their support throughout this study, and Maite Cerezo, Nikolay Erokhin, Ivan Fufachev, Tatyana Strukova, and Sergey Zykov for help and company in the field. This study has been partly supported by the programs of Ural Branch of the Russian Academy of Sciences 12-4-7-022-Arctic and 15-15-4-35-Arctic, and by the Norwegian Environment Agency. The Inter-regional Expedition Centre "Arctic" contributed funding and logistical support.

\section{REFERENCES}

Aanes, R., Sæther, B.-E., and Øritsland, N.A. 2000. Fluctuations of an introduced population of Svalbard reindeer: The effects of density dependence and climatic variation. Ecography 23(4):437-443.

http://dx.doi.org/10.1111/j.1600-0587.2000.tb00300.x

AMAP (Arctic Monitoring and Assessment Programme). 2011. Snow, water, ice and permafrost in the Arctic (SWIPA): Climate change and the cryosphere. Oslo, Norway: AMAP. 
Angerbjörn, A., Tannerfeldt, M., Bjärvall, A., Ericson, M., From, J., and Norén, E. 1995. Dynamics of the Arctic fox population in Sweden. Annales Zoologici Fennici 32(1):55-68.

Angerbjörn, A., Eide, N.E., Dalén, L., Elmhagen, B., Hellström, P., Ims, R.A., Killengreen, S., et al. 2013. Carnivore conservation in practice: Replicated management actions on a large spatial scale. Journal of Applied Ecology 50(1):59-67.

http://dx.doi.org/10.1111/1365-2664.12033

Bartsch, A., Kumpula, T., Forbes, B.C., and Stammler, F. 2010. Detection of snow surface thawing and refreezing in the Eurasian Arctic with QuikSCAT: Implications for reindeer herding. Ecological Applications 20(8):2346-2358. http://dx.doi.org/10.1890/09-1927.1

Bokhorst, S., Bjerke, J.W., Bowles, F.W., Melillo, J., Callaghan, T.V., and Phoenix, G.K. 2008. Impacts of extreme winter warming in the sub-Arctic: Growing season responses of dwarf shrub heathland. Global Change Biology 14(11):2603-2612. http://dx.doi.org/10.1111/j.1365-2486.2008.01689.x

Ehrich, D., Henden, J.-A., Ims, R.A., Doronina, L.O., Killengreen, S.T., Lecomte, N., Pokrovsky, I.G., et al. 2012. The importance of willow thickets for ptarmigan and hares in shrub tundra: The more the better? Oecologia 168(1):141-151. http://dx.doi.org/10.1007/s00442-011-2059-0

Eide, N.E., Stien, A., Prestrud, P., Yoccoz, N.G., and Fuglei, E. 2012. Reproductive responses to spatial and temporal prey availability in a coastal Arctic fox population. Journal of Animal Ecology 81(3):640-648. http://dx.doi.org/10.1111/j.1365-2656.2011.01936.x

Forbes, B.C., Stammler, F., Kumpula, T., Meschtyb, N., Pajunen, A., and Kaarlejärvi, E. 2009. High resilience in the YamalNenets social-ecological system, west Siberian Arctic, Russia. Proceedings of the National Academy of Sciences of the United States of America 106(52):22041-22048. http://dx.doi.org/10.1073/pnas.0908286106

Fuglei, E., Øritsland, N.A., and Prestrud, P. 2003. Local variation in Arctic fox abundance on Svalbard, Norway. Polar Biology 26(2):93-98.

Gallant, D., Slough, B.G., Reid, D.G., and Berteaux, D. 2012. Arctic fox versus red fox in the warming Arctic: Four decades of den surveys in north Yukon. Polar Biology 35(9):1421 - 1431. http://dx.doi.org/10.1007/s00300-012-1181-8

Golovatin, M.G., and Sokolov, V.A. 2009. The distribution of the Hooded Crow Corvus cornix in the tundra zone of Yamal (in Russian). Russian Ornithological Journal 18:1422-1423.

Golovatin, M.G., Morozova, L.M., and Ektova, S.N. 2012. Effect of reindeer overgrazing on vegetation and animals of tundra ecosystems of the Yamal Peninsula. Czech Polar Reports 2(2):80-91.

Grenfell, T.C., and Putkonen, J. 2008. A method for the detection of the severe rain-on-snow event on Banks Island, October 2003, using passive microwave remote sensing. Water Resources Research 44(3): W03425.

http://dx.doi.org/10.1029/2007wr005929

Groisman, P.Y., Sun, B., Vose, R.S., Lawrimore, J.H., Whitefield, P.H., Førland, E., Hanssen-Bauer, I., Serreze, M.C., Razuvaev, V.N., and Alekseev, G.V. 2003. Contemporary climate changes in high latitudes of the Northern Hemisphere: Daily time resolution. 14th Symposium on Global Change and Climate Variations, 9-13 February 2003, Long Beach, California.

https://ams.confex.com/ams/annual2003/techprogram/ paper_54814.htm

Hansen, B.B., Grøtan, V., Aanes, R., Sæther, B.-E., Stien, A., Fuglei, E., Ims, R.A., Yoccoz, N.G., and Pedersen, Å.Ø. 2013. Climate events synchronize the dynamics of a resident vertebrate community in the High Arctic. Science 339(6117):313-315.

http://dx.doi.org/10.1126/science.1226766

Hansen, B.B., Isaksen, K., Benestad, R.E., Kohler, J., Pedersen, Å.Ø., Loe, L.E., Coulson, S.J., Larsen, J.O., and Varpe, Ø. 2014. Warmer and wetter winters: Characteristics and implications of an extreme weather event in the High Arctic. Environmental Research Letters 9(11): 114021.

http://dx.doi.org/10.1088/1748-9326/9/11/114021

Henden, J.-A., Ims, R.A., Yoccoz, N.G., and Killengreen, S.T. 2011. Declining willow ptarmigan populations: The role of habitat structure and community dynamics. Basic and Applied Ecology 12(5):413-422.

http://dx.doi.org/10.1016/j.baae.2011.05.006

Henden, J.-A., Stien, A., Bårdsen, B.-J., Yoccoz, N.G., and Ims, R.A. 2014. Community-wide mesocarnivore response to partial ungulate migration. Journal of Applied Ecology 51(6):1525-1533.

http://dx.doi.org/10.1111/1365-2664.12328

Hersteinsson, P., and Macdonald, D.W. 1992. Interspecific competition and the geographical distribution of red and Arctic foxes Vulpes vulpes and Alopex lagopus. Oikos 64(3):505-515.

Ims, R.A., Ehrich, D., Forbes, B.C., Huntley, B., Walker, D.A., Wookey, P.A., Berteaux, D., et al. 2013a. Terrestrial ecosystems. In: Meltofte, H., ed. Arctic biodiversity assessment 2013: Status and trends in Arctic biodiversity. Akureyri, Iceland: Conservation of Arctic Flora and Fauna. 384-440.

Ims, R.A., Henden, J.-A., Thingnes, A.V., and Killengreen, S.T. $2013 \mathrm{~b}$. Indirect food web interactions mediated by predatorrodent dynamics: Relative roles of lemmings and voles. Biology Letters 9(6). http://dx.doi.org/10.1098/rsbl.2013.0802

Jentsch, A., Kreyling, J., and Bhnlein, C. 2007. A new generation of climate-change experiments: Events, not trends. Frontiers in Ecology and the Environment 5(7):365-374. http://dx.doi.org/10.1890/1540-9295(2007)5[365:angoce] 2.0.co;2

Kaikusalo, A., and Angerbjörn, A. 1995. The Arctic fox population in Finnish Lapland during 30 years, 1964-93. Annales Zoologici Fennici 32:69-77.

Killengreen, S.T., Ims, R.A., Yoccoz, N.G., Bråthen, K.A., Henden, J.-A., and Schott, T. 2007. Structural characteristics of a Low Arctic tundra ecosystem and the retreat of the Arctic fox. Biological Conservation 135(4):459-472. http://dx.doi.org/10.1016/j.biocon.2006.10.039

Killengreen, S.T., Lecomte, N., Ehrich, D., Schott, T., Yoccoz, N., and Ims, R.A. 2011. The importance of marine vs. humaninduced subsidies in the maintenance of an expanding mesocarnivore in the Arctic tundra. Journal of Animal Ecology 80(5):1049-1060. http://dx/doi.org/10.1111/j.1365-2656.2011.01840.x 
Killengreen, S.T., Strømseng, E., Yoccoz, N.G., and Ims, R.A. 2012. How ecological neighbourhoods influence the structure of the scavenger guild in Low Arctic tundra. Diversity and Distributions 18(6):563-574.

http://dx/doi.org/10.1111/j.1472-4642.2011.00861.x

Killengreen, S.T., Ims, R.A., Henden, J.A., Yoccoz, N.G., and Ehrich, D. 2013. Prosjekt "Fjellrev i Finnmark:" Rapport for 2008-2012 [Arctic fox in Norway: Report for 2008-2012]. Tromsø, Norway: University of Tromsø.

Klokov, K.B. 2012. Changes in reindeer population numbers in Russia: An effect of the political context or of climate? Rangifer 32(1):19-33. http://dx.doi.org/10.7557/2.32.1.2234

Magomedova, M.A., Morozova, L.M., Ektova, S.N., Rebristaya, O.V., Chernyadyeva, I.V., Potemkin, A.D., and Knyazev, M.C. 2006. Yamal Peninsula: Vegetation cover. (In Russian). Tumen, Russia: City-press.

McKinnon, L., Smith, P.A., Nol, E., Martin, J.L., Doyle, F.I., Abraham, K.F., Gilchrist, H.G., Morrison, R.I.G., and Bêty, J. 2010. Lower predation risk for migratory birds at high latitudes. Science 327(5963):326-327. http://dx.doi.org/10.1126/science.1183010

Meltofte, H., Barry, T., Berteaux, D., Bültmann, H., Chistiansen, J.S., Cook, J.A., Dahlberg, A., et al. 2013. Synthesis: Implications for conservation. In: Meltofte, H., ed. Arctic biodiversity assessment: Status and trends in Arctic biodiversity. Akureyri, Iceland: Conservation of Arctic Flora and Fauna. 20-65.

Miller, F.L., and Gunn, A. 2003. Catastrophic die-off of Peary caribou on the western Queen Elizabeth Islands, Canadian High Arctic. Arctic 56(4):381 - 390.

http://dx.doi.org/10.14430/arctic635

Moen, J. 2008. Climate change: Effects on the ecological basis for reindeer husbandry in Sweden. Ambio 37(4):304-311. http://dx.doi.org/10.1579/0044-7447(2008)37[304:cceote]2.0. $\operatorname{co} ; 2$

Mueller, R.C., Scudder, C.M., Porter, M.E., Trotter, R.T., III, Gehring, C.A., and Whitham, T.G. 2005. Differential tree mortality in response to severe drought: Evidence for longterm vegetation shifts. Journal of Ecology 93(6):1085-1093. http://dx.doi.org/10.1111/j.1365-2745.2005.01042.x

Newton, I., Davis, P.E., and Davis, J.E. 1982. Ravens and buzzards in relation to sheep-farming and forestry in Wales. Journal of Applied Ecology 19(3):681-706. http://dx.doi.org/10.2307/2403275

Norwegian Directorate for Nature Management. 2011. Norwegian action plan for the lesser White-fronted Goose Anser erythropus. DN-Report 2011.

http://www.piskulka.net/literature/AP/lwfg_ssapNorway2011.pdf

Post, E., Forchhammer, M.C., Bret-Harte, M.S., Callaghan, T.V., Christensen, T.R., Elberling, B., Fox, A.D., et al. 2009. Ecological dynamics across the Arctic associated with recent climate change. Science 325(5946):1355-1358.

http://dx.doi.org/10.1126/science.1173113

Rennert, K.J., Roe, G., Putkonen, J., and Bitz, C.M. 2009. Soil thermal and ecological impacts of rain on snow events in the circumpolar Arctic. Journal of Climate 22(9):2302-2315. http://dx.doi.org/10.1175/2008jcli2117.1
Restani, M., Marzluff, J.M., and Yates, R.E. 2001. Effects of anthropogenic food sources on movements, survivorship, and sociality of Common Ravens in the Arctic. The Condor 103(2):399-404.

http://dx.doi.org/10.1650/0010-5422(2001)103[0399:eoafso]2.0 .co;2

Rodnikova, A., Ims, R.A., Sokolov, A., Skogstad, G., Sokolov, V., Shtro, V., and Fuglei, E. 2011. Red fox takeover of Arctic fox breeding den: An observation from Yamal Peninsula, Russia. Polar Biology 34:1609-1614.

http://dx.doi.org/10.1007/s00300-011-0987-0

Savory, G.A., Hunter, C.M., Wooller, M.J., and O’Brien, D.M. 2014. Anthropogenic food use and diet overlap between red foxes (Vulpes vulpes), and Arctic foxes (Vulpes lagopus) in Prudhoe Bay, Alaska. Canadian Journal of Zoology 929(8):657-663. http://dx.doi.org/10.1139/cjz-2013-0283

Sokolov, A.A. 2003. Functional relationships between the Roughlegged Buzzard (Buteo lagopus) and small rodents in the southern shrub tundra of Yamal (In Russian). PhD thesis, Ekaterinburg, Russia

Sokolov, V., Ehrich, D., Yoccoz, N.G., Sokolov, A., and Lecomte, N. 2012. Bird communities of the Arctic shrub tundra of Yamal: Habitat specialists and generalists. Plos One 7. http://dx.doi.org/10.1371/journal.pone.0050335

Sokolova, N.A., Sokolov, A.A., Ims, R.A., Skogstad, G., Lecomte, N., Sokolov, V.A., Yoccoz, N.G., and Ehrich, D. 2014. Small rodents in the shrub tundra of Yamal (Russia): Density dependence in habitat use? Mammalian Biology 79(5):306-312. http://dx.doi.org/10.1016/j.mambio.2014.04.004

Stickney, A.A., Obritschkewitsch, T., and Burgess, R.M. 2014. Shifts in fox den occupancy in the greater Prudhoe Bay area, Alaska. Arctic 67(2):196-202. http://dx.doi.org/10.14430/arctic4386

Tannerfeldt, M., Elmhagen, B., and Angerbjörn, A. 2002. Exclusion by interference competition? The relationship between red and Arctic foxes. Oecologia 132(2):213-220. http://dx.doi.org/10.1007/s00442-002-0967-8

Walker, D.A., Raynolds, M.K., Daniëls, F.J.A., Einarsson, E., Elvebakk, A., Gould, W.A., Katenin, A.E., et al. 2005. The circumpolar Arctic vegetation map. Journal of Vegetation Science 16(3):267-282. http://dx.doi.org/10.1111/j.1654-1103.2005.tb02365.x

Wernberg, T., Smale, D.A., Tuya, F., Thomsen, M.S., Langlois, T.J., de Bettignies, T., Bennett, S., and Rousseaux, C.S. 2013. An extreme climatic event alters marine ecosystem structure in a global biodiversity hotspot. Nature Climate Change 3:78-82. http://dx.doi.org/10.1038/nclimate1627

Wilmers, C.C., Stahler, D.R., Crabtree, R.L., Smith, D.W., and Getz, W.M. 2003. Resource dispersion and consumer dominance: Scavenging at wolf- and hunter-killed carcasses in greater Yellowstone, USA. Ecology Letters 6(11):996-1003. http://dx.doi.org/10.1046/j.1461-0248.2003.00522.x 